\title{
After Contemporary Art: Actualization and Anachrony
}

\author{
Dan Karlholm
}

\begin{abstract}
A BSTRACT Departing from a critical assessment of the most widespread and initiated definitions of Contemporary Art from the last decade and a half, sustaining a world-wide discourse on contemporary art and contemporaneity, this article will deal with two aspects of an immodest proposal captured by the keywords actualization and anachrony. While current discussions on contemporary art are arguably reproducing modernist assumptions on the primacy of innovation, bolstered by a veiled avant-garde logic, the proposal to regard contemporary art as actualized art upsets not only ideas on what art after postmodernism might mean, but the whole edifice of historicist historiography. An anachronic perspective, a bi- or polychronic situatedness of the work of art, could be used to liberate art from being defined according to its unique descent, and to embrace, instead, a chronologic open to art's continuous "life" through its successive aesthetic accessions and actualizations in time.

KEYWORDS Contemporary art, Conceptualism, Postmodern, Actualization, Anachrony
\end{abstract}

\section{Introduction}

One reason why the issue of contemporaneity has created such a stir among art historians is that our discipline has been obsessed with time - in the form of history - since its modern inception in the nineteenth century. Even Heinrich Wölfflin, who is typically dismissed as a psychologically inclined formalist, insisted that any form or stylistic combination had a double root, which could explain it: its internal morphology and its external embeddedness, i.e. an intrinsic history of style related to an extrinsic history of culture. ${ }^{1}$ No less than two histories are here taken to shape and determine works of art. Numerous variants of this model have constituted, by and large, the discipline of art history. A crisis has occurred, however, about the role and legitimacy of history in art history. A previous crisis, erupting in the 1980 s as a reaction to theoretical and political shifts occurring widely in the 1960s and 70s, concerned the other part of the discipline: art, or what was to be counted as art, by whom and how. ${ }^{2}$ History - also in art history - is typically contrasted with the present or contemporary. But when history in art history runs into crisis, is left behind or is indeed itself relegated to a merely historical realm, it seems we are left with contemporary. This state of affairs challenges the 
entire structure of a discipline identified with a preoccupation with the past, the no more, the merely historical - although, of course, the discipline was once founded on a massive repression of the thesis that art in contemporaneity is dead or ended, by G. W.F. Hegel's account. ${ }^{3}$

In this article I hope to make clear that such a dichotomy - contemporary now versus historical past - is untenable. Starting with a critical assessment of the most widespread and established definitions of contemporary art from the last decade and a half, sustaining a worldwide discourse on contemporary art and contemporaneity, I will focus on two aspects of an immodest proposal captured by the keywords actualization and anachrony. While current discussions on contemporary art are arguably reproducing modernist assumptions on the primacy of novelty and innovation, bolstered by a veiled avant-garde logic, my proposal to regard contemporary art as actualized art upsets not only ideas on what art after postmodernism might mean, but the whole edifice of historicist historiography. An anachronic perspective, a bi- or polychronic situatedness of the work of art, could be used to liberate art from being defined according to its unique descent, and to embrace, instead, a chronologic open to art's continuous "life" through its successive aesthetic accessions and actualizations in time. I will proceed by sticking to the words of my title, beginning with "after."

\section{After}

The first word of this text is certain to make some people uncomfortable, as it may indicate that the former phenomenon (contemporary art) is no more. As if the linguistic fashion of the day had dispensed with this denomination and were on to something else, a newer new or whatever. Read this way, the perfectly benign and neutral preposition after is understood as a loaded post-phenomenon, like those that for a long time added theoretical allurement, even weight, to things or phenomena adorned with this preposition. ${ }^{4}$ I have deliberately refrained from using the post-prefix, though, precisely to avoid such connotations, and to prevent new discursive combinations from piling up over postindustrialism, postmodernism, poststructuralism, postcolonialism etcetera. Nor will I speak about "post-contemporary art" - a term in some use (by Fredric Jameson et al.) already in the early 1990s, before the whole contemporaneity debate broke loose. ${ }^{5}$ Such a term would immediately transform a preposition (which seeks only to pass beyond, move behind and do something else) to a Latin prefix glued forever to its linguistic host, so that we are graced with postcontemporary as an awkward update of 
contemporary. This would furthermore perpetuate a modernist logic of innovation as well as willingly prolong a tainted aftermath, defined by what is allegedly past or no-longer operative while, nevertheless, still sticking to the phenomenon. What I wish to do instead - and this may sound naïve - is merely to stop discussing contemporary art the way this has been done in the last decade and a half. I will offer a counterdiscursive determination, rather than definition, of what contemporary art might mean, without any illusions of persuading the mighty institutions of the art world to change their game - modernist to the bone - of trying to promote the latest, valorize the newest, and navigate toward the latest version of an avant-garde or cutting edge activity.

What my "after" aims to signal is simply that we let the prevailing discourse surrounding contemporary art rest for a while. This discourse stems from a massive increase of contemporary art on the global art market, in publishing, criticism, curating, from the escalation of centers, museums and other institutions of and for contemporary art, to a worldwide shift of emphasis among students on all levels, which will likely shape and transform art history in the foreseeable future. Behind this discourse, I discern an attitude, which I have termed contemporalism. Expressing this sea change, putting this viral hegemony into words and sketching a diagnosis serves to start actively imagining different futures for art and art history. ${ }^{6}$ The prospect of effecting this monster is of course bleak, to judge from the increasing complacency within the art world at large to not just settle for this state of affairs, but to revel in it. Many players of the art world seem comfortable making themselves at home in this new homelessness correlated with a temporal assessment of our time as a no-time, a-chronic, a new atemporal temporality. A framework for these ideas was constituted by Hegel's words on the end of history, but in the short memory of the present moment, so-called posthistory is generally associated with the emblematic year of 1989, which is to make a long and convoluted story very short. As this date is typically connected with Francis Fukuyama's article "The End of History?" which draws on Hegel's diagnosis of such an end with the Battle of Jena in 1806, the need to extend the historical frame ought to be evident. ${ }^{7}$ No conceptual fatigue is discernible when it comes to expressing the new sustainability, however, as witness the recent MoMA-exhibition The Forever Now: Contemporary Painting in an Atemporal World, where we learn that the concept of atemporality was coined by science-fiction author William Gibson in 2003, and that it can now be put to use on a kind of abstract art painting (oil on canvas mostly). These painters deal in and with "style," 
Laura Hoffman explains, and would never "use a past style in an uninflected manner; in other words, as a readymade" or as appropriation a key term for so-called postmodernism. ${ }^{8}$ How are we to understand this prognosis? Would these artists create their new styles in an atemporal bubble, forever and ever? As if Modernism was not over and like there was no after-modern tomorrow? Is this example of art, which looks like leftovers from the 1980s, the ever-present art form from now on? However amusing science fiction may be, the scientific fact is that the prospect of a prolonged future as such is seriously threatened in view of a climate change with partly irreversible environmental damages. To entertain the very idea of a forever now is evasive at best. The very concept of now, especially connected to time, is highly pertinent, however, provided it is not used in the sense of something instantaneous but as extended. From such a perspective, now would not signify atemporal limitlessness but a moving stretch of time long enough to embrace present and history, now and then, but short enough for us to operate within this period. Most important to recall is that then is always and forever a part of every now.

It used to be the case that contemporary implied, by necessity, a temporary state, the newest phase soon to be superseded by newer creative eruptions. Not so anymore: Contemporary is now about to designate a permanent state, not to say stasis, however much this is also conceived as a state of "permanent transition," which has been assigned to both Modernism, by Peter Osborne with reference to Theodor Adorno, and to contemporary art, by Terry Smith. ${ }^{9}$ Permanent transition, of course, is life itself - human and non-human life as such, on a sub-individual level, that is.

\section{Contemporary Art}

Let me turn now to some of the most ambitious attempts at defining contemporary art, by Arthur Danto, Hans Belting, Terry Smith and Peter Osborne. I will only be able to abbreviate crudely what I perceive as the most specific traits of these definitions. Already before contemporary art had risen to its current position of super-ism - the one and only ism which is not even an ism (save for its contemporalist heart) - Arthur C. Danto diagnosed a post-historical situation, modeled on Hegel's wellknown narrative on the virtual end of art in his lectures on aesthetics. Danto argues, from the early 1980 os to the late 1990s, that the philosophy of art history came to a close and was resolved with a work such as Andy Warhol's Brillo Box (1964). After the end of art, a post-historical freedom reigns, in which new art will be produced, but no longer with defining 
links to art's previous history. ${ }^{10}$ My problem with Danto's thesis is that he makes use of a too rigid philosophy of history, destined to come to an end in history, which means the end of history, after which only posthistory prevails. He also pays too little respect to earlier avant-garde acts, Marcel Duchamp's in particular. And instead of taking Hegel's argument as his model, he would have been better off reading Martin Heidegger on the origin of the artwork, which was in part a direct response to Hegel's gloomy prediction, and which would have furnished Danto with a more fruitful theory of art's capacity to "ground" history and literally project rather than reject history. The latter, of course, would presume that Danto was a phenomenologist instead of a self-proclaimed essentialist analytical philosopher. ${ }^{11}$

Hans Belting argued for something similar to Danto's thesis in his essay The End of the History of Art? first published in German in 1983, in a period stamped by postmodernism, critical historiography and revisionist "new" art history. ${ }^{12}$ Belting claimed that artists no longer felt connected to the master narrative of the history of art, but used history, instead, as a resource and database (one among many) for whatever they would propose as new work. This would mean, as he also later confirmed, that art history was over. ${ }^{13}$ While this was an early acknowledgement of an important point that only became a truism in the digital age, Belting's current argument is a different one, which has everything to do with the globalization of the world, especially from 1989 on. This movement leads, allegedly, to a dissolution of what Danto had called "the artworld,"14 in favor of a plurality of art worlds where substantial parts of the practices of art are no longer even legible as "art" but only as "cultural production." Arguing convincingly for the obsolescence of a distinction between high art and folk craft or "ethnic art," he forwards the argument that a "post-ethnic" situation prevails, along with the global interconnections, where old notions of heritage and placing, are no longer accredited powers of definition and identification. ${ }^{15}$ While this may support a fair redistribution of powers in the global art world(s) and serve to democratize the field of art - a good cause as such - it also runs the risk of cutting the historical link to the intellectual infrastructure of art, including the theory and philosophy of art, which is itself a historical thus precarious formation, and the only thing that could explain or justify that some nondescript pile of junk installed on a gallery floor, for example, is actually a specimen of high art with a maximum of cultural value. Many contemporary artists happily dispense with the concept of art - or so they say - maybe 
because they see no point in using it or think they are ahead of it, or because they are just badly informed about the historicity of their own privileges or of the fact that they are the puppets of an institutionalized avant-garde which spurs them to keep breaking away and spitting obsessively on the culture of art. It is all very understandable but also very naïve. Art without its genealogy is nothing. Nothing, that is, but culture (parts of which could be called aesthetic). And culture is everything, from cooking to sports, sex to business, fashion to gambling. Belting's openness to the prospect that art production could just as well morph into culture production also risks effectuating a return to the premodern concept of art, where only its values of skill, handicraft and relative beauty would prevail.

For all his learning and theoretical brilliance, Peter Osborne - philosopher, critic and connoisseur of conceptual art - has settled for the following rather simple definition: "contemporary art is postconceptual art." By the latter he means art stamped by the conditions established with the advent of conceptual art practices from the late 1960s onward. The use of "post" in this instance is perplexingly different from how this is used in most combinations, such as postindustrialism or postmodernism, namely to signify that the root word here is overcome or superseded, yet still needed to define the future, for as long as this phase is believed to last. Post in postmodernism signifies a state where modernism has been annulled, evacuated or erased, whereas post in postconceptualism means art with a conceptual heritage. The first post is negative and signals "from this moment on, no more," where the second positive post, on the contrary, means "from now on" or "ever after." ${ }^{16}$ The latter usage of post is to my mind not only historicist - all post-designations are - but too empirically coupled with the specific conceptual art movement of the 1960s. I would rather say that the latter movement - signified by Joseph Kosuth and his American peers - came to affirm, enact and dramatize certain conditions for art making that had been around for some time. This phase is part of what Thierry de Duve has termed "generic art," which congealed, so to speak, during "the long 196os," to form the ground - and here I am in agreement with Osborne - on which current contemporary art still treads. ${ }^{17}$ I prefer to talk about this new condition as "panconceptualism," instead, which alleviates art from the burden of being defined according to a specific art historical movement. Panconceptualism cuts much deeper than postconceptualism, by including as well art that has nothing whatsoever to do with conceptual art properties like a predilection for information, seriality, documentation, dry humour 
or administrative aesthetics. If art can look like anything, be almost anything, a categorical concept of art is operative, with the power of defining all examples of the category of art. ${ }^{18}$

Terry Smith has written extensively on many aspects of contemporary art, which he connects with "world currents" instead of a global network. ${ }^{19}$ In his compressed history it is "blindingly obvious" that contemporary art hits the art world in the 1980s:

In the visual arts, the big story, now so blindingly obvious, is the shift - nascent during the 1950s, emergent in the 1960s, contested during the 1970s, but unmistakable since the 1980 - from modern to contemporary art. ${ }^{20}$

Is it not rather the author who is obviously blinding us with a narrative where what used to be called postmodernism is no longer even a part of the recent history of art? The claim is also plainly false, since it is only from around the late 1990s that the canonical cutting edge is no longer automatically associated with postmodern art but referred to instead as just contemporary, understood, at first, as a neutral term, and as a rejection of the ism-phenomenon. By all standard accounts, however, contemporary today means, unless otherwise specified, something which comes after postmodernism, despite a much longer history that stretches down to the early nineteenth century. ${ }^{21}$ The real 1980s, in the Western venues that counted, was all about postmodernism. ${ }^{22}$ And when one would address contemporary art, it was either postmodern or referring to art from the larger part of the twentieth century. ${ }^{23}$

To Smith, contemporary art conforms to a set of "conditions of contemporaneity." He also analyzes this art in three currents, a rather rigid model that runs the risk of petrifying his whole theory of alleged permanent worldwide transition. Contemporary art is "different in kind from modern art [which is] contemporary in and of itself, and in ways more fundamental than those in which previous art has been contemporary." ${ }^{24}$ Phrases such as these belie the obvious fact that contemporary is a relative term, doubly so, in fact: Relative to us here now, who are each other's contemporaries, and relative vis-à-vis older, past or historical art. The first sense could also be subjected to a further, crucial distinction: A first sense which merely indicates neutral temporal relations among contemporaries, and a further sense, which sifts the wheat from the chaff, or the majority of artists anywhere or at any given moment of the now from the privileged circle of artists valorized as part of the Contemporary club. 


\section{Actualization}

It is not my intention to add yet another definition to the ones I have presented and criticized above. Positing contemporary art as actualized art, however, is more of a meta-definition about what we tend to do when seeking to define some art as contemporary. No one involved in the serious philosophical business of coming up with increasingly economical and ultimately final definitions of art would take such a definition seriously; it is a non-definitive, non-definition definition, more of an idea or a critical suggestion about what contemporary might mean if we shrug off all criteria based on empirical content (as by Belting or Osborne) or historical timing (as by Danto or Smith).

What would it entail, then, to regard contemporary art as actualized art? According to the OED, the word actualization refers to "[a] making actual; a realization in action or fact." ${ }^{25}$ It refers to an act of doing something in order for something to happen, for some transformation to occur. It is a practice-based performative. Actual is actually a synonym to real. Actualize means "[t]o make actual, to convert into an actual fact, to realize in action," ${ }^{26}$ which fits perfectly the capacity of art in the panconceptual era, where anything in principle can become art, be realized as art, provided it is (1) proposed as such, by those with the power of proposing these things (artists), and (2) received as such by the art world. In contradistinction to the other definitions I have discussed, this variant is not based on a historical turning point, although it too of course has its historical point of emergence and its historically traceable conditions of possibility in the long 1960 .

Translated into Swedish (or any of the Germanic Scandinavian languages) the word actual is the same as aktuell, but the English translation of the latter word is topical. Here is another sphere of relevance for my actualization thesis, along with references to realization or making real. The root word of topical is topic (subject) from the Greek topos, meaning place. Despite appearances, con-temporary art is in fact not primarily about time. For the painter Gerhard Richter "art is always contemporary: it's not a thing that is periodically over and done with. It has nothing whatever to do with time." ${ }^{27}$ I agree, it has more to do with certain clusters of topics deemed relevant (topical) by a certain art world community or discursive topology. The word contemporary in contemporary art has two main references captured by the prefix "con" (with); a largely quantitatively based, which relates to all of us who share something by literally sharing the same time, and a qualitative one, which refers to those relatively few in sync with contemporaneity or samtiden in Scandi- 
navian, which is a discursive structure of topical topics (social, political, economic, ecological and so on) deemed urgent to deal with, connect to, etcetera. The latter is infinitely more consequential than the former one, to understand the weight involved in being summoned as an artist under the contemporary caption, to being accredited relevance to these most pressing tasks of our time. Most artists, all over the world, working and exhibiting at the same time right now are not deemed contemporary on qualitative grounds. Contemporary is, to cite another artist, Wyndham Lewis, "a cultural elite." ${ }^{28}$ Contemporary is a term of value, a critical term of praise, which is partly covered and made ideologically effective by reference to the neutral connotation of art made now. Would the art world settle for "contemporary forever," ${ }^{29}$ however, it would either be the definitive death knell for most artists on the globe trying to work and exhibit "now," given the tacit criteria of selectivity of the word contemporary, or, on the contrary, perhaps the final dissolution of such qualitative judgements: If everything from now on is literally contemporary, no distinctions have been or indeed can be drawn and the word loses its meaning.

Before proceeding to my final part, I would like to mention what I see as the greatest benefits of my counter-definition definition: It is contrary to the other definitions - non-normative and non-qualitative, since also not only ugly or disturbing works but bad or trivial works could be actualized or brought to our attention now. This may appear offensive, a sign of bad taste and not much of an advantage at all, but the point is only to refrain from judging what is important, cutting edge or future canon material, which keeps the whole machinery of hierarchical art history going. Here is a chance, instead, of taking aspects of the contemporary designation - traits to do with what we communally find interesting to address, dwell upon, assess and so on - and mobilize them to other uses than the promotion of novelties. This is also to follow in practice what has been laid down theoretically, with the all-embracive conceptual concept of art in the 1960s, namely that what is (to be counted as) art is not a certain category of physical objects with certain art properties, but a decision that "from now on, $\mathrm{X}$ is also (to be regarded as) art." The latter could be rephrased as X being actualized or realized as art by a certain community of the art world. Such a scope would include all of the categories that the conventional definitions cover, canonical high art material, which is bestowed an enormous amount of attention or active actualization, but it would also - quite subversively - potentially include other and older art as well. There is no reason to discriminate between actualizable art on the basis of when it was once created. The 
habitual ageism of the contemporary art discourse is to be avoided. The parameter of creation, of craft and the literal making of things at a specific moment in time, was paramount to a chronotopic definition of art, from Hegel to all of mainstream art history. It is still the commonsense definition. But in my view, also so-called historical art can become contemporary, depending on the interest bestowed upon it. Actualized art has a tract with memory, with what the Greeks called anamnesis, the memory of actualization, where what will be called memories - i.e. fragments of the past - are recalled and recollected in the present. ${ }^{30}$ This fits with Duchamp's legacy as well; it is not what the artists did, but what the art institution does that ultimately defines or confirms something as art.

My quasi-definition is importantly not about dissolving or neglecting historical differences in some relativist or pluralist posthistorical mode. On the contrary, temporal differences are not only still preserved and acknowledged, they are also highlighted by this proposal. Such differences are brought to the fore when a work of art with its immanent temporality (which always exceeds its purported historical determination to include its material aging or enduring semiotic transformations as well) is brought to play in another temporal art space. Already in his critique of historicism, Hans-Georg Gadamer underlined that "temporal distance is not something that must be overcome" in his version of hermeneutics. ${ }^{31}$ Here too, a distance is temporarily bridged, but by no means annulled or erased. This could hopefully lead to a more complex historical model, which is the topic of my last part.

\section{Anachrony}

Chronology itself is obviously challenged these days by versions of achronic posthistory, but chronology is not the enemy as such - it only refers to the measurement of time, as the nineteenth-century dictionaries had it. It has accumulated so many misunderstandings and clichés, however, that we would be better equipped, perhaps, with the term chronologic, which has to be determined by every specific usage. It has become mandatory to bemoan the monolithic character of the one, "homogenous empty time" of ordinary history, and embrace, instead, a plurality of times, a.k.a. hetero-chronicity. ${ }^{32}$ To choose the latter, however, not only presumes a homochronic norm; it helps to preserve it. And it often fails to distinguish between objective and subjective modes, cosmological and phenomenological times, for example, which has always been around, and socio-political and cultural temporalities, which need always to be historically specified and established. 
Similar problems occur when scholars embrace anachrony's linguistic sibling: anachronism, which is presented as both negative and positive, a sin of the historian, on the one hand, and a refreshing alternative for a different kind of historian, on the other hand. At the same time, many argue that anachronism is indeed unavoidable in historical scholarship, a precondition for historicizing some other time that is inevitably read through the lens of a temporal alien or latecomer. ${ }^{33}$ As a critical alternative to historicism, I believe that anachronism is too biased a term to use. In its character of violation of the norm, it serves, consciously or not, to maintain the norm of flawless historical procedure. Anachrony, on the other hand, tilts the whole received historical operation to the side and opens up to a new sensitivity for the project of determining the temporalities of historical works of art. ${ }^{34}$ This would entail, in my view, that we need to both historicize and temporalize artifacts like artworks, revealing, first of all, their historical context, which is taken to comprise the entire expanding space between its birth and its continued duration and present existence, and, second of all, determine its potentially multiple temporalities - as both belated and ahead of a sequence, for example, or as constituted by two or several temporal layers.

Anachronic historiography appears paradoxical compared to the standard historical text, organized as a unilinear unfolding of events across a timeline. Anachronic history does not seek "causal connections," it is more about tracing effects, or what has de facto happened genealogically to the work through its journey in time and space. Where all conventional history is, in truth, a kind of pre-history, a coming to grips with how the work came about, anachrony is better described as afterhistory (not to be mistaken for some atemporal featureless posthistory). ${ }^{36}$ According to what James Elkins has termed "normal art history"37 - of which the contemporary art discourse is a true testament - a work of art is born at a specific moment in time, which will forever stamp its historicity and determine what could be said about it. This default mode conforms as well to what Keith Moxey has termed art history's "Hegelian unconscious." ${ }^{38}$ Anachronic art history, if we could imagine that, is receptive instead to what the work is recorded doing in relation to its forward leaning, futural "life" where it is involved in recovering pre-conditions, remembering, postponing, enduring or striking up new acquaintances that will affect its being-in-the-world. The old question of establishing what the work is with reference to what it was no longer works. The new question is to establish what the work is with reference to what it is in the process of becoming. 


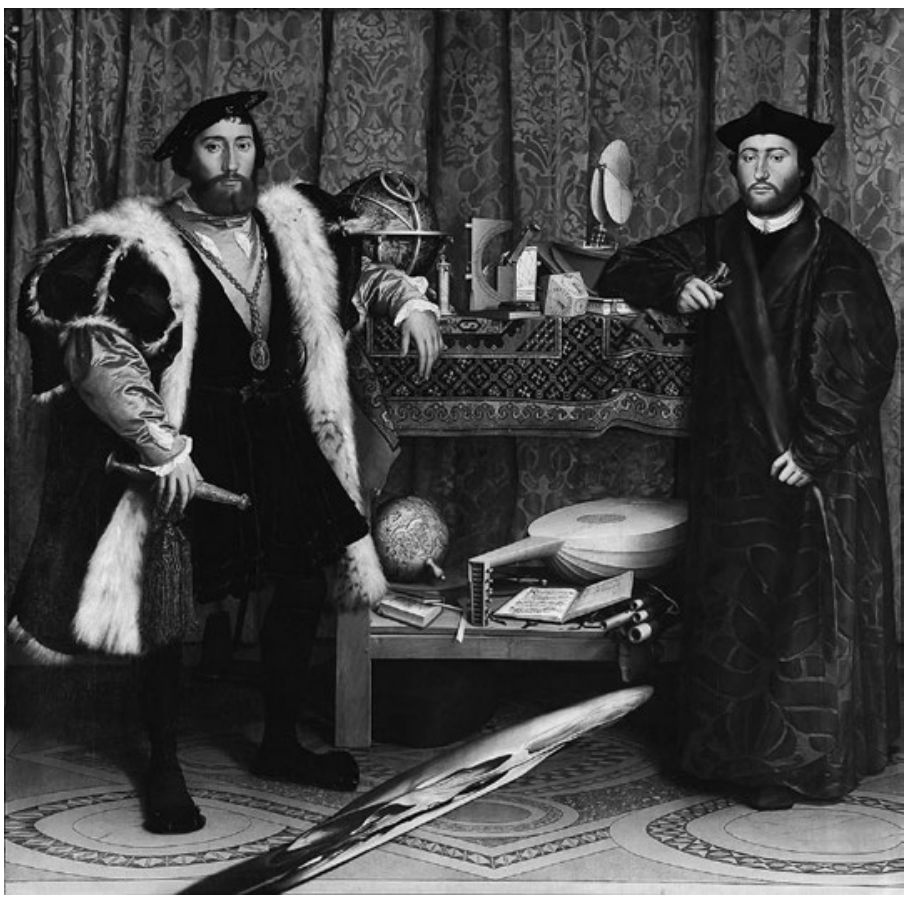

Plate 1: Hans Holbein the younger, The Ambassadors (1533), National Gallery, London.

Anachrony shares some family resemblances with the optical construction of anamorphosis, where the picture is only unveiled through an instrument - a distorted mirror - that translates the distorted painted form (as a historically enigmatic, strange object) into legible form. Two distortions hence bring about the "true" image. The most famous is perhaps the skull superimposed upon the Hans Holbein painting The Ambassadors (1533), where the distorted figuration in mid-air (possible to spot in its undistorted reality only from an oblique angle) spells death. In order to be perceived, or better: received, the image must be read through a specific operation that restores and returns the image to its postponed "happening of truth" in Heidegger's phrase. The discovering of death as the underside of being or the "possibility of the absolute impossibility of Da-sein," to quote Heidegger again, presents itself as recovered. ${ }^{39}$ Underlining the temporal complications here we could say that death is a present absence brought about by a recovering of the future.

To illustrate what anachronic historiography is up against, I would like, finally, to pick a few examples - knowing that the particularities of these choices threaten to invalidate some of my more general propositions. My first two examples are extreme: 

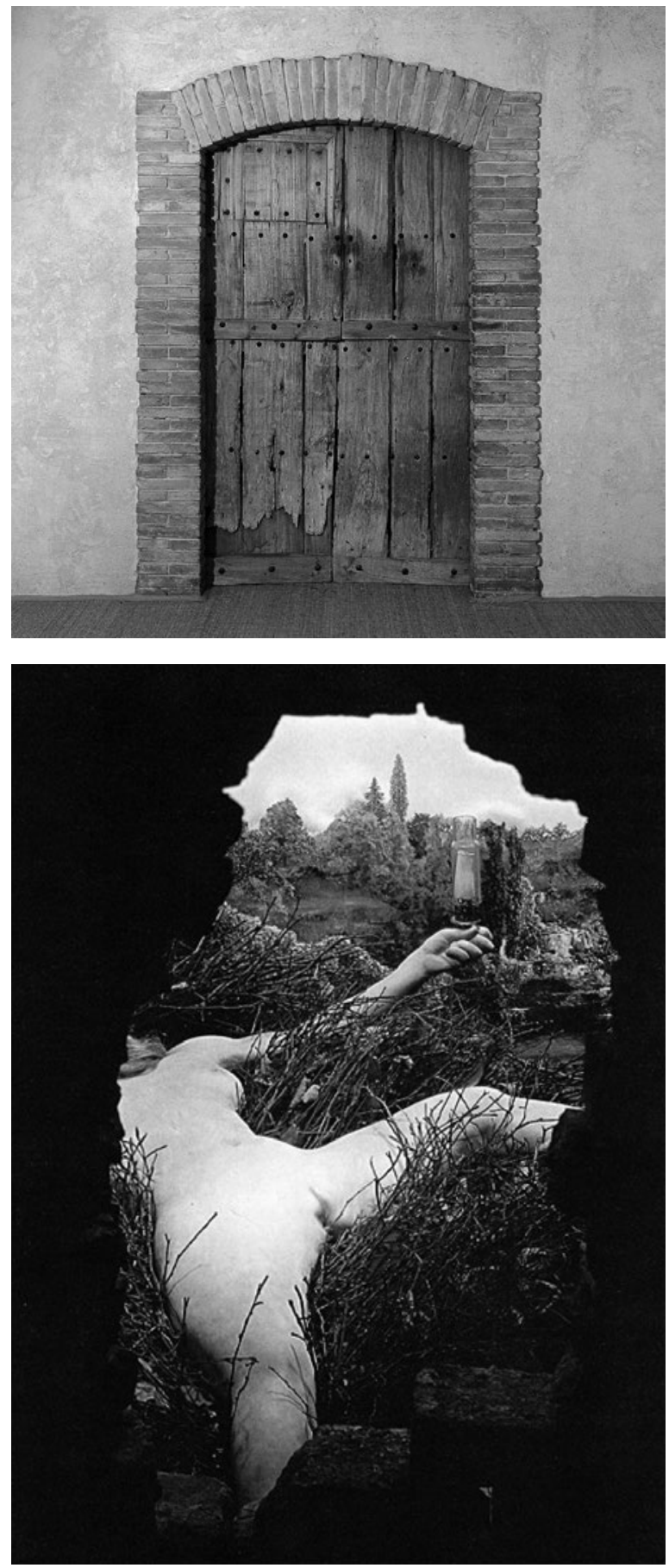

Plate 2: Marcel Duchamp, Étant donnés: 1 la chute d'eau, 2 le gaz d'éclairage (1945-68), Philadelphia Museum of Art. 
As is well known, Marcel Duchamp's (1887-1968) last work was conceived immediately after the Second World War, and was worked on in secret for more than two decades. It is an installation avant la lettre finally presented to the art world in 1969, in the heyday of conceptual art, during what had become postwar, a cold war, and the Vietnam War in America. This was a surreal eruption within the very institution of art, permanently installed as part of the museum itself (which is odd enough), namely in the Philadelphia Museum of Art in the form of a curious diorama with its shocking hidden content. ${ }^{40}$ The temporality of the work is intriguing: It needs, first of all, to be recovered in two steps, where the content of the work is only disclosed to us after we have crossed a spatial divide in time, and brought ourselves up against the old wooden door and peaked in. Second of all, since this work was calculated to be revealed to the world only after the artist's death, it is literally post-contemporary. The work was born old, displaced and in the same year that Joseph Kosuth wrote about certain new art conditions "after Duchamp." ${ }^{141}$ This is Duchamp after Duchamp. While his Large Glass was more or less intentionally delayed, this piece is in time, but uncannily untimely at the same time.

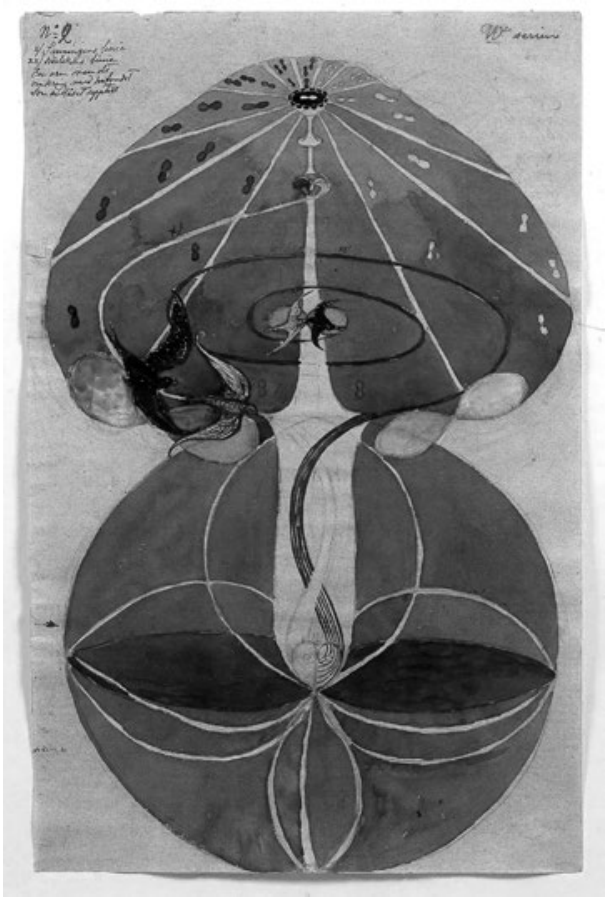

Plate 3: Hilma af Klint, Untitled (no date). 
Swedish artist Hilma af Klint (1862-1944), a couple of decades older than Duchamp, led two lives, so to speak. ${ }^{42}$ One as a modern painter, trained at the Royal Academy in Stockholm, and another as a self-proclaimed medium for esoteric wisdom. The latter project kept her preoccupied throughout her life from around 1905. This work - hundreds of images and thousands of pages of notes - was never exhibited in her lifetime. It was amassed from within the circle of five female friends De Fem (The Five) of which only some were trained as artists. Hilma af Klint intended for some of these images to be displayed in a suitable temple-like building, which, alas, was never erected. After being denied approval from her mentor Rudolf Steiner, af Klint vowed to let this work remain unseen and un-exhibited until two decades after her death. It came to be more or less neglected until 1986, when a show in Los Angeles displayed her work alongside abstract artists like Kazimir Malevich, Wassily Kandinsky and Frantisek Kupka. ${ }^{43}$ Since then, the conventional art historical issue has been whether or not she merits being included among this group of male pioneers of abstraction, due to her images of geometric forms and non-figuration painted a few years before the first abstract painting appeared around 1910.44 Since she was no part of that culture, however, and nursed no intentions of participating in it either, the answer is no. She did not even regard her esoteric project as art, but after the belated arrival of her work to the postmodern or contemporary art world, from the 1980 s onward, where it inspires artists and artistic researchers, these images have indeed become art, actualized art, and thus, in my book, contemporary art in our (extended) sense of the word..$^{45}$

An image by German artist Hannah Höch (1889-1978), a contemporary with Duchamp, entitled Angst (Anxiety) is in many respects a typical photomontage, a format connected to the experimentations by Höch and Raoul Hausmann around 1920. ${ }^{46}$ It features a black and white photograph of a head, over which a big red mouth has been pasted over the mouth up to the nose of the figure. Also two oversized eyes seem to have been crudely sewn onto the black Gestalt. What is untypical about the image is not so much the look of it, since it does have a few distinct traits of Höch's earlier production, but its date. What does a Dada photomontage by one of the greatest in the genre mean as a new or "contemporary" artwork in 1970? Is it Neo-Dada now - a tag pinned to the American followers of Duchamp in the 1950s and 6os? No, it is Dada, and yet it is not, since Dada is no more at this moment in time. The Dada movement, we read in the surveys of modern art 
history, started in 1916 and was dissolved a few years into the 1920 . Hannah Höch's Anxiety appears unmoored in time, unbound, floating backwards and forwards along the currents of time. It points, among other things, to an earlier work by her, with the same title, very different in style and temperament (a mix of Edvard Munch and Ernst Ludwig Kirchner, perhaps). This namesake from 1936 looks older than the image from 1970 despite the fact that the latter has so much in common with the photomontages of vintage Dada of the early $1920{ }^{47}$ The work of 1970 also appears to point ahead, towards the feminist art movement that was about to revolutionize traditional art history, and spotlighted women's precarious situation as mothers, lovers and domestic slaves, so to speak, while evoking in equal measures the past of blackface painting and minstrel shows of the nineteenth and early twentieth centuries. ${ }^{48}$ The image also actualizes now contemporary artwork by Candice Breitz and Makode Linde, for example, well past the feminist movement of the 1970 s and 8os, who establish new links to these older traditions of racism, slavery and colonial violence. ${ }^{49}$ The very title of the work evokes moreover the philosophy of Søren Kierkegaard and Jean-Paul Sartre. To arrest the associations and paraphrase one of the greatest Danish authors, finally, Hans Christian Andersen, we could describe this image as an ugly duckling of art history, anachronic to its core. But the moral of this story is of course familiar to us all: this ugliness is only another beauty, displaced and out of joint. Time alone will eventually reveal its pre-programmed end.

\section{Illustrations}

Plate 1: Hans Holbein the younger, The Ambassadors (1533), National Gallery, London (https://commons.wikimedia.org/wiki/File:Hans_Holbein_the_Younger_The_Ambassadors___Google_Art_Project.jpg)

Plate 2: Marcel Duchamp, Étant donnés: 1 la chute d'eau, 2 le gaz d'éclairage (1945-68), Philadelphia Museum of Art. Screenprint of Étant donnés from the museum website: http://www.philamuseum.org/collections/permanent/65633.html

Plate 3: Hilma af Klint, Untitled (no date) (https://commons.wikimedia.org/wiki/ File:Hilma_af_Klint__no_date___Untitled_o2.jpg?uselang=sv)

\section{Notes}

1. Heinrich Wölfflin, Principles of Art History: The Problem of the Development of Style in Later Art, trans. M. D. Hottinger (New York: Dover, 1950).

2. To the Eurocentric art category was added "images" of all kinds as well as 
new theoretical approaches, from fields such as Marxism, semiotics, psychoanalysis, feminism. In the 1990s, postcolonial studies were importantly added to the mix. All in all, this contributed in reforming the core of the discipline of art history throughout the world.

3. Dan Karlholm, Art of Illusion: The Representation of Art History in NineteenthCentury Germany and Beyond (Bern: Peter Lang, 2004).

4. While the title of David Joselit's book After Art flirts with this loaded quality, the study is dedicated to expanding "the definition of art to embrace heterogeneous configurations of relationships or links" that art becomes involved in once, or after, it is presented to the world. Furthermore: "In its connotations of an 'afterimage' or its implication of a life of images in circulation following the moment of production, after posits continuity and reverberation, rather than rupture. What results after the 'era of art' is a new kind of power that art assembles through its heterogeneous formats." David Joselit, After Art (Princeton and Oxford: Princeton University Press, 2013), 2, $90 \mathrm{of}$.

5. Fredric Jameson and Masao Miyoshi (eds.), The Cultures of Globalization: PostContemporary Interventions (Durham: Duke University Press, 1998). For a quick overview of the rather large and somewhat dispersed discourse on "post-contemporary" as such, see Wikipedia: https://en.wikipedia.org/wiki/Post-contemporary.

6. Dan Karlholm, Kontemporalism: Om samtidskonstens historia och framtid (Stockholm: Axl Books, 2014), 9-20.

7. Francis Fukuyama, "The End of History?," The National Interest, Summer 1989. For a historical overview, cf. Lutz Niethammer, Posthistoire: Has History Come to an End? (1989), trans. Patrick Camiller (London: Verso, 1994). Cf. also Karlholm, "Då: historia efter posthistoria," in Historiens hemvist, eds. Hans Ruin et al. (Stockholm: Makadam förlag, 2016).

8. Laura Hoptman, The Forever Now: Contemporary Painting in an Atemporal World (New York: The Museum of Modern Art, 2014), 13, 21.

9. Peter Osborne, Politics of Time: Modernity and Avant-Garde (London: Verso, 1995), 14; Terry Smith, Contemporary Art: World Currents (London: Laurence King, 2011), 316.

10. Arthur C. Danto, After the End of Art: Contemporary Art and the Pale of History (Princeton, N.J.: Princeton University Press, 1997).

11. Martin Heidegger, "The Origin of the Work of Art," in Heidegger, Poetry, Language, Truth, trans. Albert Hofstadter (New York: Harper, 1971); Arthur C. Danto, "The End of Art: A Philosophical Defense," History and Theory 37, no. 4 (1998) (Theme issue: Danto and his Critics: Art History, Historiography and After the End of Art), 127-43.

12. Hans Belting, The End of the History of Art?, trans. Christopher S. Wood (Chicago: The University of Chicago Press, 1987). Cf. also Belting, Art History 
after Modernism, trans. Caroline Saltzwedel and Mitch Cohen (Chicago: The University of Chicago Press, 2003).

13. Belting, Art History after Modernism.

14. Arthur C. Danto, "The Artworld," The Journal of Philosophy 61, no. 19 (1964).

15. Hans Belting, "From World Art to Global Art: View on a New Panorama," in The Global Contemporary and the Rise of New Art Worlds, eds. Hans Belting, Andrea Buddensieg and Peter Weibel (Cambridge, Mass.: MIT Press, 2013), 17885. Cf. also Belting "Contemporary Art is Global Art: A Critical Estimate," in The Global Art World: Audiences, Markets, and Museums, eds. Hans Belting and Andrea Buddensieg (Ostfildern: Hatje Cantz, 2009), 38-73.

16. Osborne, Anywhere or Not at All: Philosophy of Contemporary Art (London: Verso, 2013).

17. On "the long 1960s," see Karlholm, Kontemporalism, passim; Thierry de Duve, Kant after Duchamp (Cambridge, Mass.: MIT Press, 1998).

18. Karlholm, Kontemporalism, 162-68.

19. Terry Smith, Contemporary Art, and references.

20. Smith, What is Contemporary Art? (Chicago: The University of Chicago Press, 2009), 5 .

21. Linda Nochlin, Realism (London: Penguin, 1971); Richard Meyer, What Was Contemporary Art? (Cambridge, Mass. and London, 2013).

22. A classic example is Brian Wallis (ed.), Art after Modernism: Rethinking Representation (New York: The New Museum of Contemporary Art, 1984).

23. E.g. Laszlo Glozer (ed.), Westkunst: Contemporary Art Since 1939 (Cologne: DuMont, 1981).

24. Smith, Contemporary Art, 8-13.

25. Oxford English Dictionary, 1989, Vol. 1, p. 132 ("actualization").

26. Ibid. ("actualize").

27. Gerhard Richter, "Interview with Rolf Schön," in Writings 1961-2007, eds. Dietmar Elger and Hans Ulrich Obrist (New York: D.A.P., 2009), 61.

28. Wyndham Lewis, The Demon of Progress in the Arts (London: Methuen, 1954), 66.

29. Dan Karlholm, "Contemporary, Now and Forever," Art History 36, no. 1 (2013).

30. Cf. Paul Ricoeur, Memory, History, Forgetting, trans. Kathleen Blamey and David Pellauer (Chicago: University of Chicago Press, 2004), part 1.

31. Hans-Georg Gadamer, Truth and Method (London: Sheed \& Ward, 1988), 264. 32. Walter Benjamin, "Theses on the Philosophy of History," in Illuminations: Walter Benjamin Essays and Reflections, ed. Hannah Arendt, trans. Harry Zohn (New York: Schocken, 1968), 261. For an excellent critical survey, cf. Keith Moxey, Visual Time: The Image in History (Durham: Duke University Press, 2013), 37-50. 
33. Georges Didi-Huberman, Confronting Images: Questioning the Ends of a Certain History of Art, trans. John Goodman (University Park: Pennsylvania State University Press, 2005).

34. Alexander Nagel and Christopher S. Wood, Anachronic Renaissance (New York: Zone Books, 2010), 13.; Karlholm, Kontemporalism, 276-86.

35. Heidegger, "The Origin of the Work of Art," 70.

36. Cf. Karlholm, "Då: historia efter posthistoria." My perspective is in part indebted to Michel Foucault's genealogy: Karlholm, Kontemporalism, 315-18; Foucault, "Nietzsche, Genealogy, and History," in Foucault, Language, CounterMemory, Practice, ed. Donald F. Boucahard (Ithaca: Cornell University Press, 1977), 139-64.

37. James Elkins, Our Beautiful, Dry, and Distant Texts: Art History as Writing (University Park: Pennsylvania State University Press, 1997), 11-13.

38. Keith Moxey, "Art History's Hegelian Unconscious: Naturalism as Nationalism in the Study of Early Netherlandish Painting," in The Subjects of Art History: Historical Objects in Contemporary Perspectives, eds. Mark A. Cheetham, Michael Ann Holly, Keith Moxey (Cambridge: Cambridge University Press, 1998), 25-51.

39. E.g. Heidegger, "The Origin of the Work of Art," 37, and Being and Time, trans. Joan Stambaugh (Albany: State University of New York Press, 1996), 232.

40. Marcel Duchamp, Étant Donnés, eds. Michael R. Taylor et al. (Philadelphia, Pa.: The Philadelphia Museum of Art, 2009).

41. Joseph Kosuth, "Art after Philosophy" (1969), in Joseph Kosuth, Art after Philosophy and After: Collected Writings, 1966-90 (Cambridge, Mass.: MIT Press, 1991), 3-32.

42. Åke Fant, Hilma af Klint: Ockult målarinna och abstrakt pionjär, exh. cat. Moderna Museet (Stockholm: Raster, 1989); Hilma af Klint: Abstrakt pionjär, eds. Iris-Müller Westermann and Jo Widoff (Stockholm: Moderna Museet, 2013).

43. The Spiritual in Art: Abstract Painting 1890-1985, eds. Maurice Tuchman et al., exh. cat. Los Angeles County Museum (New York: Abbeville Press, 1986).

44. E.g. Inventing Abstraction 1910-1925: How a Radical Idea Changed Modern Art, ed. Leah Dickerman, exh. cat. (New York: Museum of Modern Art, 2012).

45. This is a very short abbreviation of my argument in Kontemporalism, 292300. Cf. also The Legacy of Hilma af Klint: Nine Contemporary Responses, eds. Daniel Birnbaum and Ann-Sofi Noring (Stockholm: Moderna Museet; London: Koenig Books, 2013).

46. Hannah Höch, eds. Dawn Ades et al., exh. cat. Whitechapel Gallery, London (Munich: Prestel, 2014).

47. E.g. Hannah Höch: Gotha 1889-1978 Berlin, exh. cat. (Gotha: Museen der Stadt Gotha, 1993), 172. 
Dan Karlholm

48. E.g. Linda Nochlin,"Why Have There Been No Great Women Artists?", in Nochlin, Women, Art and Power and Other Essays (London: Thames and Hudson, 1989), 145-78 and Robert C. Toll, Blacking Up: The Minstrel Show in NineteenthCentury America (London: Oxford University Press, 1977).

49. Candice Breitz: http://www.candicebreitz.net/; Makode Linde:

https://sv.wikipedia.org/wiki/Makode_Linde. 